\title{
Some Gemological Challenges IN IDENTIFYING BLACK OPAQUE Gem Materials
}

By Mary L. Johnson, Shane F. McClure, and Dino G. DeGhionno

A mong the most difficult gems to identify are those that are black and opaque (or nearly so). In general, any gem material can be opaque because of inclusions, any black opaque material can be fashioned, and any porous material can be dyed. Thus, to identify a black opaque material, every possible mineral, and many rocks and manufactured substances, must be considered. Microscopic appearance, refractive index, specific gravity, and other properties (such as magnetism or radioactivity) provide useful clues, but in most cases advanced identification techniques (X-ray diffraction, EDXRF spectroscopy) are necessary, and even these may not be conclusive. Black opaque pyroxenes, amphiboles, and spinel-group minerals are especially challenging to identify.

ABOUT THE AUTHORS

Dr. Johnson is a research scientist, Mr. McClure is supervisor of identification services, and Mr. DeGhionno is staff gemologist at the Gemological Institute of America Gem Trade Laboratory in Carlsbad, California.

Acknowledgments: This article is dedicated to the late Robert C. Kammerling, former vice president of Identification and Research and Development at GIA GTL, Santa Monica, Califomia, for his inspiration. (He also provided the spinel-group mineral samples.) For critical review of the manuscript, the authors also thank Tom Moses and Mene Reinitz, both of New York GIA GTL, and John I. Koivula, Carlsbad GIA GTL.

Gems \& Gemology, Vol. 32, No. 4, pp. 252-261. c) 1996 Gemological institute of America.

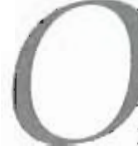

ne of the most challenging problems in gemology is that of determining the identity of a black opaque gem material-hereafter called a "black opaque." Such materials are a mainstay of the jewelry business, primarily as side stones, decorative elements in multi-stone mosaics, and in men's jewelry. Treated black chalcedony ("black onyx"), black jade, and hematite traditionally have been the black opaques in greatest demand. As a variety of quartz, "black onyx" is probably the most familiar durable black opaque to lapidaries and gem cutters. Today, it is a popular medium for artistic carvings, many of which have been incorporated into fine jewelry (figure 1).

In recent years, various materials have been misrepresented as "black onyx" or "black jade" to meet the trade's need for calibrated goods in high-volume markets. Members of the trade, in turn, have been sending samples to identification laboratories to ensure that the material has been properly represented, so that they can sell it honestly. Usually, individual items sent to the GIA Gem Trade Laboratory (GIA GTL) for identification are representative of larger lots.

The purpose of this article is to provide a set of procedures by which to identify black opaques (that is, materials that are black or almost black and opaque or nearly so). The examples used are drawn primarily from our experience at GIA GTL. Not all black opaques are included here, as that is beyond the scope of a single article (and almost any gem material, by virtue of inclusions, can become a "black opaque"). Because so many materials-both common and exotic-may be used as black opaques, any set of identification procedures must take all possibilities into consideration, not just a few. For example, black jade (nephrite or jadeite), "onyx," and hematite each have many imitations. Also, natural-color black diamonds may be confused with diamond imitations and treated-color diamonds. In the last few years, other black opaque materials have become increasingly available, such as the amphibole ferrohomblende (sold as black "gem barkevikite") and various spinel-group minerals (figure 2). Still another challenging problem is that of identifying black opaque polycrystalline aggregates, or rocks. 


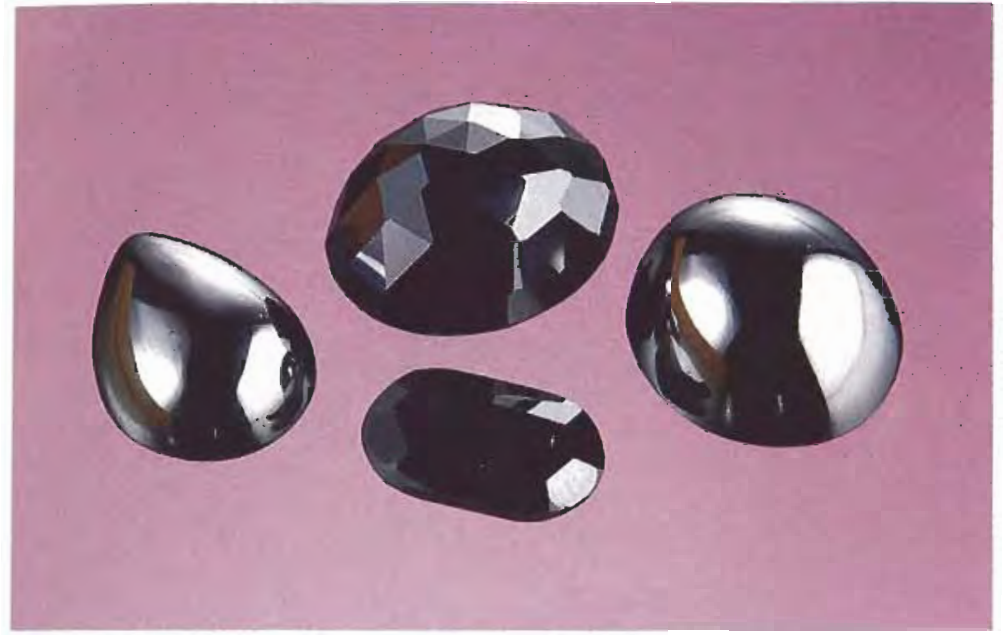

Figure 2. These four opaque black stones, which range from 1.88 to $13.63 \mathrm{ct}$, are hercynite (the two faceted stones) and magnetite, spinel-group minerals from the Bo Phloi region of Thailand. Photo by Maha DeMaggio.

If a microscope with an analyzer is available, a polarizer can be placed over the light source to obtain additional information. Anisotropic /uniaxial and biaxiall minerals have different refractive indices with different directions of polarized light, so the relative reflectivities of adjacent grains in an aggregate may change as the analyzer is rotated. Some highly reflective materials, such as the black opaque minerals graphite and enargite, may show pleochroism in reflected light.

Observation of the sample's luster can be very important (again, see figure 2). Black opaques can

Figure 3. The contrast in relief seen in reflected light in this dark green fuchsite (muscovite) mica is due to the presence of harder minerals, such as quartz, in this aggregate material. Photo by John I. Koivula; magnified $15 x$.

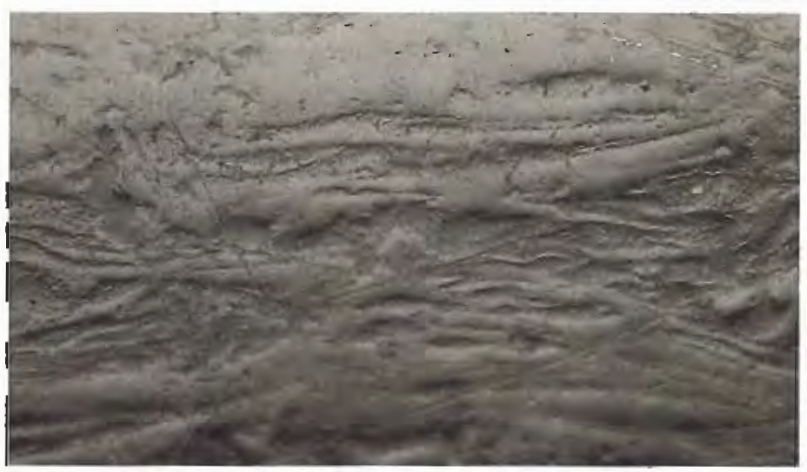

have any type of luster and, in general, "higher" lusters (adamantine or metallic) correspond to high R.I. values. However, the apparent luster also may be affected by the quality of the polish on a fashioned gem.

In many cases, a black opaque is not completely black or opaque when a very thin region is viewed with a strong beam of light. Fiber-optic illumination in conjunction with magnification is ideal for this purpose (Koivula, 1982). Materials that have a black appearance overall may look green, brown, red, blue, purple, gray, or the like, at these intensely lit thin edges. Sometimes growth structures are more visible in thin edges with strong transmitted light (figure 5) than with reflected light. Inclusions--such as gas bubbles in manufactured glass, and stretched gas bubbles and irontitanium oxide inclusions in natural volcanic glass (obsidian; see, e.g., Gübelin and Koivula, 1986, p. 285) - may also be seen.

Some black opaques display asterism (see, e.g., Kane, 1985 [sapphire]; Liddicoat, 1989 [diopside]; Koivula and Kammerling, 1990a [ekanitel; and Koivula et al., 1993b [irradiated quartz]), which can be an important consideration for identification. Chatoyancy is also seen occasionally (as in opalKoivula and Kammerling, 1990b). Both of these phenomena may be very weak, so strong pinpoint illumination also should be used to search for them.

In those cases where a material is black because of inclusions, it often helps to try to determine which opaque material is responsible for coloring the unknown. Strong, low-angle oblique illumination can be used, with magnification, to distinguish

Figure 4. The crystals in this sample of (manufactured) devitrified glass have a higher refractive index than the glass matrix, and so they reflect more light. Photomicrograph by John I. Koivula; magnified $20 x$.

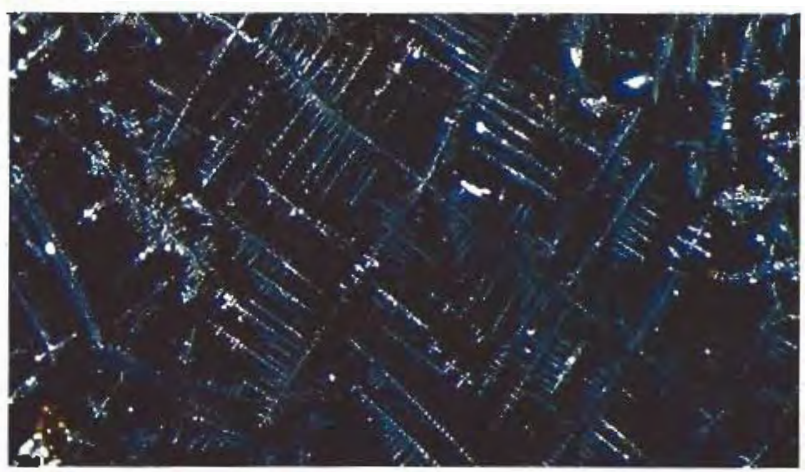




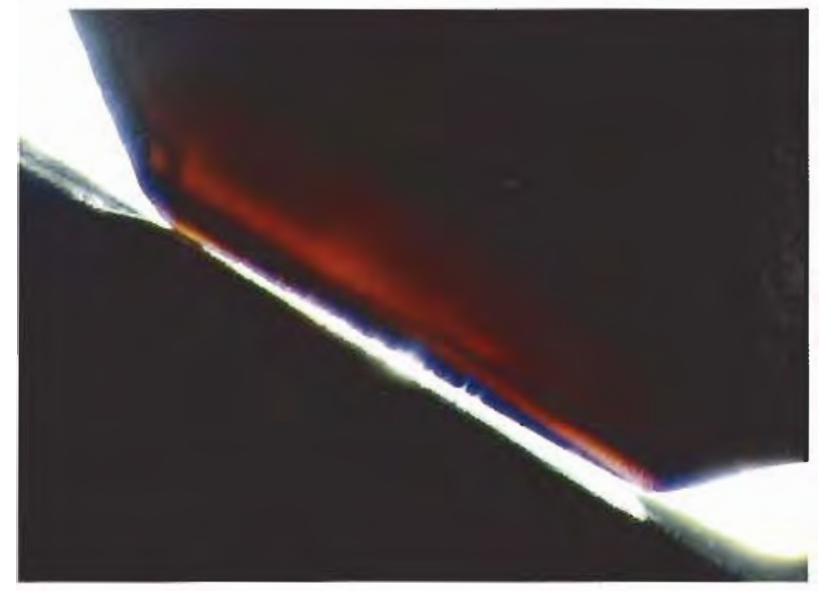

Figure 5. The banding in this "black onyx" cabochon is visible only on a very thin edge with strong fiber-optic illumination. The black chalcedony may have been a banded agate before being treated to produce the black color, or it could have been a chalcedony in which different layers selectively absorbed the coloring agent. Photomicrograph by John I. Koivula; magnified 10x.

(for instance) between metallic iron oxides such as hematite, which appear reddish brown when lit from the side (figure 6), and titanium-bearing oxides such as ilmenite, which may appear white when lit from the side (because of surface alteration

Figure 6. The large hematite crystal in this quartz/magnetite/hematite cabochon looks red along $a$ very thin edge; this red color is seen when the sample is examined with low-angle oblique illumination. Photomicrograph by John I. Koivula; magnified 15x.

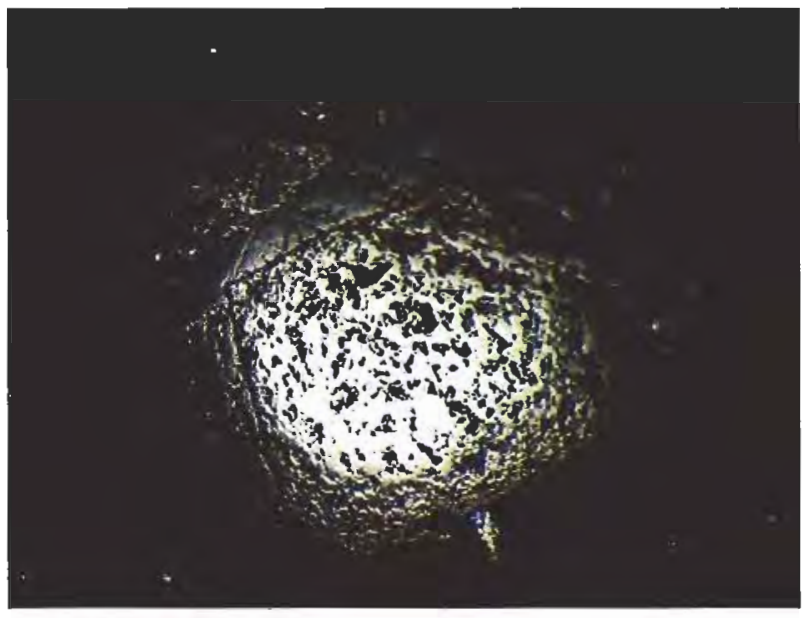

into white so-called "leucoxene" [Deer et al., 1966, pp. 418-419], figure 7). Similarly, the opaque iron sulfides pyrite and pyrrhotite look brassy yellow in reflected light. This technique may also provide clues to the identity of a metallic-luster opaque.

Many other optical tests-such as observing the absorption spectrum, checking the optic sign, or looking for pleochroism-are not feasible when testing black opaques. (However, a reflected-light spectrum sometimes can be obtained from opaque samples: Kammerling et al., 1990.) Fortunately, the refractive index (or indices) of an opaque material still can be measured, although many materials, especially those with metallic lusters, have indices that are over the limits of a standard refractometer. Measurements should be taken from several places on a black opaque to check for multiple phases, or to determine if the material is doubly refractive. (As used here, "phases" refers only to solid phases, including distinct minerals, glass, plastic filler, etc.)

Other Physical Tests. Specific gravity can be extremely valuable for distinguishing among single-crystal materials, especially those with refractive indices greater than 1.81. It is somewhat less reliable for aggregates and porous materials. Note that some materials give inconsistent specific gravity values, including the hercynite sample described below. Also, hydrostatic specific gravity measurements are less precise than, for example, refractive index measurements.

Figure 7. The ilmenite crystal in this black labradorite moonstone cabochon looks white when viewed with low-angle oblique illumination. Photomicrograph by John I. Koivula; magnified 20x.

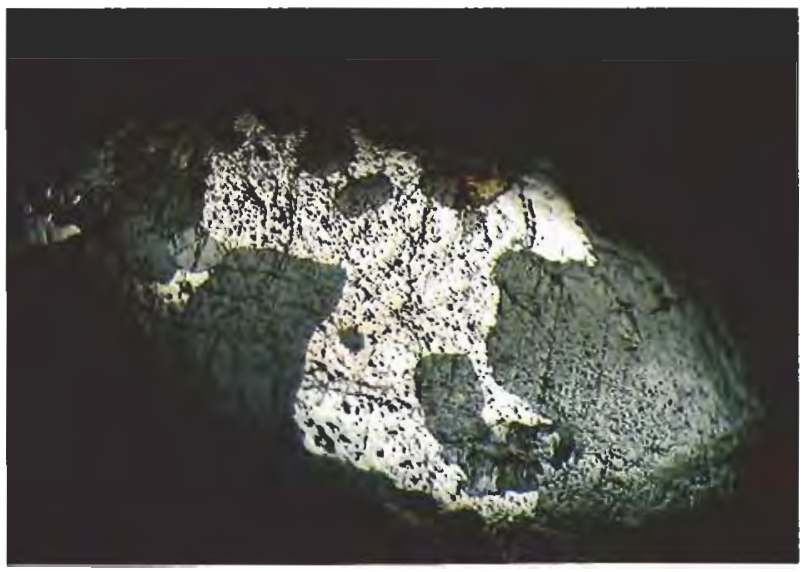


Various other tests may be useful or even diagnostic for certain materials. One common test is the observation of luminescence to long- or short-wave ultraviolet radiation. For example, some black diamonds fluoresce (Kammerling et al., 1990). Certain black opaques, notably magnetite, are strongly attracted to magnets, as are some other spinel-group minerals (e.g., some hercynite: Johnson, 1994) and some hematite (Fryer et al., 1984). The streak test (scratching an inconspicuous corner of the sample across an unglazed porcelain plate) must be made carefully, as it is a destructive test, but it can provide distinctive information about certain materials. For example, the iron oxides - magnetite, hematite, and goethite-have black, red, and brown streaks, respectively. However, for aggregate materials with small grain sizes, the low-angle oblique illumination test mentioned above provides the same information as a streak test, without the risk of damaging the sample. Some low-luster materials, such as jet and plastics, react to the thermal reaction tester ("hot point $t^{\prime \prime}$ with diagnostic aromas.

Some materials are electrically conductive. These will give a positive response to an electrical conductometer-or even to an electrical multimeter, which is available at most hardware stores. For example, a diagnostic test for manufactured yttrium iron garnet, YIG, is that it does not conduct electricity (Kammerling et al., 1990). However, practically any mineral or rock can appear black and opaque because of included graphite, which conducts electricity; consequently, such a material might give a positive response to an electrical conductivity test even though the host material is not electrically conductive.

Finally, a few materials are innately radioactive, such as pitchblende (uraninite; Fuhrbach, 1987) and dark green to black-appearing ekanite (see, e.g., Kane, 1986a; "Gem News," 1987). Others are radioactive because of treatment, such as treatedcolor black diamonds (see, e.g., Reinitz and Ashbaugh, 1992; Koivula et al., 1992c). Radioactivity can be detected by means of handheld detectors (such as Geiger counters), by the fogging of photographic film (see, e.g., Fuhrbach, 1987), or with more sophisticated techniques (Ashbaugh, 1992).

In many cases, however, the information provided by the tests described above will not be sufficient to identify a black opaque (figure 8). For these pieces, more advanced testing, requiring more sophisticated equipment, is necessary.
Advanced Tests. Two advanced testing procedures will usually identify any unknown black opaque: Xray powder diffraction analysis and energy-dispersive $\mathrm{X}$-ray fluorescence (EDXRF) spectroscopy. In X-ray powder diffraction analysis, a minute amount of material is scraped from an inconspicuous spot on the sample. The resulting fine powder is attached to a small glass fiber "spindle" that is then mountedalong with a strip of X-ray sensitive film-in a special diffraction camera. Next, the sample is exposed to a strong beam of nearly monochromatic X-rays. The lattice of atoms (atomic structure) of the rotating powdered sample causes the X-rays to be diffracted and expose arc-shaped regions on the film. By measuring the positions of these arcs, and estimating their relative intensities, we can compare the Xray powder diffraction pattern of the unknown material to diagnostic patterns for known materials. Because the powder sample is usually taken from only one or a few inconspicuous spots, care must be exercised to ensure that the area sampled is representative of the piece as a whole; this is especially difficult to guarantee for black aggregates.

In the second test, EDXRF spectroscopy, the entire sample is exposed to a strong X-ray source, which induces the elements in the sample to produce (or "fluoresce") secondary X-rays. Because each element in the sample produces X-rays with a characteristic set of energy levels, the sample's chemical composition can be approximated by collecting and counting these $\mathrm{X}$-rays. (Note that the elements within the sample absorb some or all of each other's emitted X-rays, as well as the source X-rays, and can cause one another to fluoresce; consequently, the quantitative or even semi-quantitative determination of a sample's chemistry is much more complicated and, in general, requires appropriate and wellunderstood standards.)

The combination of X-ray powder diffraction and EDXRF analyses can usually determine both the structure and the chemistry of a sample. Frequently, this information is sufficient to identify the material. However, we may not be able to separate minerals that form groups or series /such as pyroxenes, amphiboles, and spinels) from other members of the same mineral group without further testing, such as the destructive or relatively inaccessible tests described below.

Petrographic and Other Geologic Tests (Not Recommended). Because of their destructive nature, certain standard geologic tests may be inap- 
propriate for gemstones. The simplest of these is hardness testing, which requires scratching the sample one or more times. Detailed optical information about transparent minerals can be obtained from thin sections of that material-that is, slices with an ideal thickness of about $30 \mu \mathrm{m}$ that have been polished on both sides. Many minerals that appear to be opaque at a thickness useful for jewelry are transparent or translucent in thin section; however, most customers do not want a representative slice taken from their valuable gem!

Quantitative chemical techniques, such as electron microprobe analysis and scanning electron microscopy--energy dispersive spectroscopy (SEM-EDS), require costly equipment, trained personnel, and special sample preparation. Some other techniques, such as classical wet chemistry and the more modern gas chromatography/mass spectrometry (GC/MS), require complete destruction of at least part of the sample. Other sophisticated tests-transmission electron microscopy, the "ion probe," single-crystal X-ray diffraction, and the like-require special preparation and/or some sample destruction in order to characterize a mineral completely. Consequently, such tests are usually inappropriate for isolated gem samples, although they may be required to characterize fully a new gem material.

\section{SPECIFIC IDENTIFICATION EXAMPLES}

Several examples of black opaque materials that have been seen at GIA GTL are given in table 1, along with an abbreviated list of their properties and some references for further information. This list is certainly not complete, as any gem material may be black and opaque if it contains a sufficient amount of dark inclusions (as is the case with black diamonds, for example). Furthermore, virtually any dark-colored mineral that occurs in aggregates that are large and coherent enough can be fashioned into a cabochon, and any porous material-such as calcite, dolomite, chalcedony, and the like-can be dyed black (figure 9). Three especially challenging identification problems are discussed below: rocks (aggregate materials), pyroxene- and amphibole-group minerals, and black spinel-group minerals.

First Example: Aggregate Materials (Rocks). Inspection with reflected light provides the best clue to the appropriate procedure for identifying a black opaque aggregate material. Are there differ-

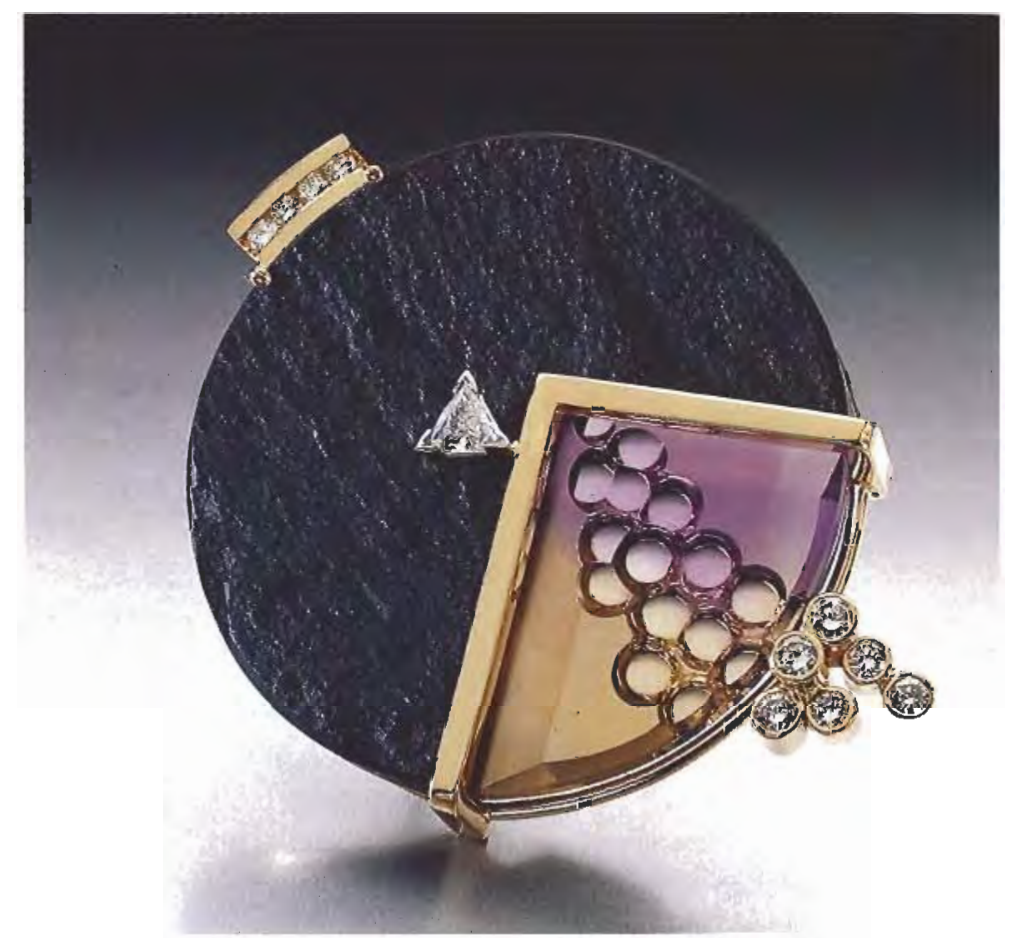

Figure 8. It would probably be necessary to use advanced testing methods, such as EDXRF spectroscopy and X-ray powder diffraction analysis, to determine which black material was used in this carving by Steve Walters. The carving is set with amethyst-citrine and diamonds in a convertible enhancer pin designed and manufactured by David W. Lisky and Christopher Engelken, of Christopher David Designs, Milwaukee, Wisconsin. Photo by John Parish.

ences in polishing hardness, relief, or reflectivity, indicating the presence of multiple phases or of multiple orientations of the same mineral phase? If so, what are the relative amounts of the phases present? (Relative amounts are determined by estimating the proportion of different distinct areas, a standard practice in sedimentary petrology.) In most cases, only phases comprising $25 \%$ or more of the sample are identified by GIA GTL.

Sometimes, the surface areas of individual phases in a rock are large enough so that individual R.I. values can be determined. The specific gravity, on the other hand, is an aggregate property: The specific gravity we determine for an aggregate sample should agree with the weighted average of the S.G. values of the individual phases present. (If it does not, the material may be different below its surface-e.g., hollow, or zoned around a denser 
TABLE 1. Gemological properties of some black opaque gem materials. ${ }^{a}$

\begin{tabular}{|c|c|c|c|c|c|}
\hline Name & R.I. & S.G. & Luster & Comments & References \\
\hline Hemalite & $2.94-3.22$ & $4.95-5.16$ & Metallic & Sometimes magnetic & $\begin{array}{l}\text { Fryer et al. (1984), Liddicoat (1989), } \\
\text { Webster (1994) }\end{array}$ \\
\hline Uraninile & Nol available & $5.2-10.0$ & Submetallic, resinous & Radioactive & $\begin{array}{l}\text { Fuhrbach (1987), Liddicoat (1989), } \\
\text { Kammerling et al. (1990) }\end{array}$ \\
\hline Diamond & 2.417 & 3.52 & Adarnantine & & $\begin{array}{l}\text { Liddicoat (1989), Crowningshield (1990), } \\
\text { Kammerling et al. (1990), Johnson (1995) }\end{array}$ \\
\hline Irradiated "black" diamond & 2.417 & 3.52 & Adamantine & $\begin{array}{l}\text { Sometimes } \\
\text { radioactive }\end{array}$ & $\begin{array}{l}\text { Liddicoat (1989), Kammerling el al. (1990), } \\
\text { Koivula el al. (1992c), Reinitz and } \\
\text { Ashbaugh (1992) }\end{array}$ \\
\hline Cassiterite & $2.006-2.097$ & 6.99 & Adamantine to vitreous & & Liddicoat (1989), Kammerling et al. (1990) \\
\hline Hausmannite & $>1.81$ & 4.84 & Adamantine & & $\begin{array}{l}\text { Kammerling et al. (1995b), observalion of same } \\
\text { material (unpublished) }\end{array}$ \\
\hline "Psilomelane" (Mn oxides) & $>1.81$ & 4.35 & Metallic to submetallic & & Webster (1994) \\
\hline $\begin{array}{l}\text { Spinel Group } \\
\text { Magnetite }\end{array}$ & 2.42 & 5.20 & Metallic & Magnetic & Deer el al. (1966), Welch (1987), Ihis work \\
\hline Hercynite & $>1.81 ; 1.835$ & 4.40 & Subadamantine & Somelimes magnetic & Johnson (1994), Webster (1994), this work, \\
\hline Spinel & 1.77 & 3.83 & Vitreous & & Fryer et al. (1982), Hurwil (1984), Webster (1994) \\
\hline Intermediale spinel-hercynite & 1.765 & 3.93 & Subadamantine to vitreous & & Koivula et al. (1993a) \\
\hline $\begin{array}{l}\text { Garnel Group } \\
\text { Andradite garnel (melanite) }\end{array}$ & 1.885 & 3.84 & Subadamantine to vitreous & & Liddicoat (1989) \\
\hline Pyrope & 1.740 & Aboul 3.72 & Vitreous & & Fryer (1988) \\
\hline Corundum (star sapphire) & $1.760-1.78$ & $3.989-4.0$ & Subadamantine & & Kane (1985), Liddicoat (1989), Webster (1994) \\
\hline $\begin{array}{l}\text { Pyroxene Group } \\
\text { Augile }\end{array}$ & $1.702-1.728$ & $3.20-3.35$ & "High" vitreous & & Hurwit (1988a) \\
\hline Diopside (star) & $1.675-1.701$ & 3.33 & Vitreous & & Liddicoal (1989), Websler (1994) \\
\hline Jadeite jade & $1.65-1.67$ & $3.20-3.34$ & Vilreous & & Liddicoal (1989), Hargell (1990) \\
\hline Tourmaline & $1.622-1.655$ & $3.15-3.2$ & Vitreous & & Liddicoal (1989), Webster (1994) \\
\hline $\begin{array}{l}\text { Amphibole Group } \\
\text { Ferrohornblende }\end{array}$ & $1.60-1.70$ & 3.36 & Vitreous & & Crowningshield et al. (1994) \\
\hline Nephrite jade & $1.600-1.641$ & $2.90-3.02$ & Vitreous & & Liddicoat (1989), Webster (1994) \\
\hline Cumminglonile-grunerite & $1.54-1.65$ & & & & Kane (1984) \\
\hline Jet & $1.59-1.66$ & $1.20-1.30$ & Resinous & & Hunwit (1985), Liddicoat (1989), Webster (1994) \\
\hline Ekanite & $1.593-1.595$ & About 3.30 & Vitreous & Radioactive & Kane (1986a) \\
\hline Labradorite teldspar & $1.560-1.568$ & 2.69 & Vitreous & Colored by inclusions & Liddicoat (1989), Webster (1994) \\
\hline Dyed chalcedony (black "onyx") & $1.530-1.539$ & $2.57-2.64$ & Vitreous & & Koivula and Kammerling (1991), Webster (1994) \\
\hline Chalcedony with "Psilomelane" & $1.535-1.539$ & $3.0-3.1$ & Metallic to submetallic & Banded & $\begin{array}{l}\text { Liddicoat (1989), Kammerling et al. (1990), } \\
\text { Koivula and Kammerling (1989) }\end{array}$ \\
\hline Coated quartz & 1,54 & & Vitreous to dull & & Hurwit (1988b) \\
\hline Dolomite & $1.51-1.67$ & $2.8-2.9$ & Vitreous & & Koivula et al. (1994), Webster (1994) \\
\hline Black coral & 1.56 & 1.34 & Resinous & & Liddicoat (1989), Webster (1994) \\
\hline Obsidian & $1.48-1.52$ & $2.30-2.50$ & Vitreous & & Liddicoal (1989), Webster (1994) \\
\hline Opal (black opaque) & 1.44 & 2.02 & Vitreous & & Koivula and Kammerling (1990b) \\
\hline $\begin{array}{l}\text { Rocks (aggregates) } \\
\text { Dotomite/quartzile sock }\end{array}$ & $1.66 \mathrm{spot}$ & 2.74 & Vitreous & & Hargett (1991) \\
\hline Basall rock & n.d. ${ }^{b}$ & n.d. & n.d. & & Koivula and Kammerling (1989) \\
\hline $\begin{array}{l}\text { Simulants } \\
\text { Cubic zirconia }\end{array}$ & 2.14 & $6.14-6.16$ & Adamantine & & Kammerling el al. (1991), Koivula et al. (1992b) \\
\hline Silicon & $>1.81$ & 2.34 & Metallic & Gray & Webster (1994), Johnson and Koivula (1996) \\
\hline "Hematine" & $>1.81$ & $4.00-7.00$ & Metallic & Magnetic & Liddicoat (1989), Webster (1994) \\
\hline YIG (yttrium iron garnet) & not available & about 6 & Vitreous to submetallic & Magnetic & Liddicoat (1989), Kammerling et al. (1990) \\
\hline Barium suifate/polymer & mid-1.50s & $2.26,2.33$ & n.d. & & Koivula el al. (1992a), Webster (1994) \\
\hline Plastics & $1.5-1.6$ & $1.05-1.55$ & Vitreous to resinous & & Liddicoat (1989), Webster (1994) \\
\hline Glass & $1.35-1.70$ & $2.51-3.21$ & Submetallic to vitreous & & $\begin{array}{l}\text { Kane (1986c), Welch (1988), Liddicoat (1989), } \\
\text { Moses (1989), Webster (1994) }\end{array}$ \\
\hline
\end{tabular}

${ }^{a}$ Arranged in approximate decreasing order of refractive index. ${ }^{b}$ n.d. = not determined. 
comment, "Petrographic testing would be necessary to fully characterize this material." This comment means that some of the "less appropriate" tests mentioned earlier would be needed to determine the exact mineral species. Sometimes the comment, "Additional minerals may be present," is added as well.

Third Example: Black Opaque Spinel-Group Minerals. The black members of the spinel mineral group present significant identification challenges, since the group contains 21 species /Fleischer and Mandarino, 1995), and many of these form complete solid solutions (similar to the garnets). However, only four of these end-members are important components of the black spinels that we have examined: spinel, hercynite, magnetite, and, to a much lesser extent, chromite (Fryer et al., 1982; Hurwit, 1984; Welch, 1987; Koivula et al., 1993a; Johnson, 1994).

Magnetite and hercynite have refractive indices that are over the limit of the standard refractometer (that is, greater than 1.81), but the R.I. of spinel can be measured, as can those of some of the intermediates between spinel and hercynite. When measurable, the R.I. of a spinel-group mineral provides an important clue about that mineral's identity.

For many of the black spinels in our experience, the measured specific gravity values 13.78-3.88 for five hercynites, including the two shown in figure 2 , and $4.81-4.83$ for the two magnetites in figure 2) are lower than those predicted by Deer et al. (1966) from end-member compositions; however, other authors cite different S.G. values for hercynite (see, for instance, Phillips and Griffen, 1981). At least some of the hercynites that we have examined, and all of the magnetites, proved to be magnetic (e.g., Johnson, 1994).

The unit-cell spacing, $a$, is the fundamental distance between identical groups of atoms in the atomic structure of an isometric crystalline material. In spinel-group minerals, this spacing can be measured by X-ray powder diffraction analysis, that is, by carefully measuring the spacings of arcs on the photographic film, with comparison to a standard, preferably one mixed with the powdered unknown (an "internal" standard).

The general formula for the spinel group is $\mathrm{AB}_{2} \mathrm{O}_{4}$, where $\mathrm{A}$ and $\mathrm{B}$ are different cation elements; spinel itself is $\mathrm{MgAl}_{2} \mathrm{O}_{4}$; and other spinelgroup minerals contain $\mathrm{Fe}, \mathrm{Zn}, \mathrm{Mn}, \mathrm{Cr}, \mathrm{V}, \mathrm{Ni}, \mathrm{Co}$,
$\mathrm{Cu}, \mathrm{Ti}$, and $\mathrm{Ge}$. (Hercynite is $\mathrm{FeAl}_{2} \mathrm{O}_{4}$, magnetite is $\mathrm{FeFe}_{2} \mathrm{O}_{4}$, and chromite is $\mathrm{FeCr}_{2} \mathrm{O}_{4}$.) All of these elements (except oxygen) can be detected by the EDXRF instrumentation available at GIA GTL, although special attention must be paid to the lightest elements, $\mathrm{Mg}$ and $\mathrm{Al}$, so that they are not overlooked. EDXRF spectroscopy is a necessary step in identifying an unknown spinel-group mineral, to make sure that no important component is overlooked.

Deer et al. (1966, p. 431) provide a calibration chart for R.I., S.G., and $a$ for six spinel-group minerals, in the two series spinel-hercynite-magnesiochromite-chromite and spinel-hercynite-magnesioferrite-magnetite. We can identify a spinel-group mineral using this chart, our determined values of R.I. and $a$, and the EDXRF results for chemistry. (Because there is some debate as to the appropriate S.G. values to use, we do not include this information.) Black spinel-group minerals examined by GIA GTL include: spinel (Fryer et al., 1982; Hurwit, 1984), hercynite (Johnson, 1994), magnetite (Welch, 1987), and an intermediate between spinel and hercynite (Koivula et al., 1993a).

\section{SUMMARY AND CONCLUSION}

Black opaque gem materials present a special identification problem, because many basic gemological identification techniques require the transmission of light through the sample. In some cases, standard examination techniques are adequate to distinguish among common black opaques, at least to some minimum level of confidence. Certain modifications of these techniques, especially visual observation with reflected light, may provide additional insights. Some specific but less routine tests (such as for magnetism) can also be very useful. Bynow-routine advanced testing procedures, such as $\mathrm{X}$-ray powder diffraction analysis and EDXRF spectroscopy, give information that cannot be obtained by standard gemological testing alone. These advanced tests are usually required to positively identify most black opaque materials. With black opaques, as with other gem materials, all of the information available should be used to identify a sample. Because they are black and opaque, some uncertainty may remain about their identity even after advanced testing. In such cases, destructive testing techniques may be the only option for positive identification. 


\section{REFERENCES}

Ashbaugh III C.E. (1992) Gamma-ray spectroscopy to measure radioactivity in gemstones. Gems es) Gemology, Vol. 28, No. 2, pp. 104-11l.

Crowningshield G.R. (1990) Gem trade lab notes: DiamondFancy black. Gems (4) Gemology, Vol. 26, No. 3, p. 221

Crowningshield G.R. (1993) Gem Trade lab notes: Iridescent orthoamphibole, "nuummite."Gems \& Gemology, Vol. 29, No. 4, p. 281.

Crowningshield G.R., Johnson M.L., Reinitz I. (1994) Gem trade lab notes: Iron-rich hornblende. Gems $\uplus$ Gemology, Vol. 30, No. 3, pp. 186-187.

Deer W.A., Howie R.A., Zussman J. (1966) An Introduction to the Rock-Forming Minerals. Longman Group, London, 528 $\mathrm{pp}$.

Fleischer M., Mandarino J.A. (1995) Glossary of Mineral Species 1995, 7th ed. Mineralogical Record, Tucson, Arizona, 280 pp.

Fryer C. (1988) Gem trade lab notes: Black pyrope garnet. Gems e) Gemology, Vol. 24, No. 2, pp. 116-117.

Fryer C., Crowningshield R.C., Hurwit K.N., Kane R.E. (1982) Gem trade lab notes: Spinel?. Gems e) Gemology, Vol. 18, No. 3, p. 173.

Fryer C., Crowningshield R., Hurwit K.N., Kane R.E. (1984) Gem trade lab notes: Hematite, magnetic. Gems ev Gemology, Vol. 20, No. 1, pp. 4647.

Fuhrbach J. (1987) Editorial forum: Want to buy a "hot diamond"? Gems $\Theta$ Gemology, Vol. 23, No. 2, p. 111.

Gem news (1987) Large ekanite found. Gems et Gemology, Vol. 23, No. 2, p. 123.

Goebel M., Dirlam D.M. (1989) Polynesian black pearls. Gems e) Gemology, Vol. 25, No. 3, pp. 130-148.

Gübelin E.J., Koivula J.I. (1986) Photoatlas of Inclusions in Gemstones. ABC Edition, Zurich, Switzerland, 532 pp.

Hargett D. (1990) Jadeite of Guatemala: A contemporary view. Gems e) Gemology, Vol. 26, No. 2, pp. 134-141.

Hargett D. (1991) Gem trade lab notes: Quartzite and dolomite bead. Gems e) Gemology, Vol. 27, No. 4, p. 251.

Hurwit K.N. (1984) Gem trade lab notes: Black spinel. Gems 4$)$ Gemology, Vol. 20, No. 2, p. 112.

Hurwit K.N. (1985) Gem trade lab notes: Carved jet. Gems e4) Gemology, Vol. 21, No. 4, pp. 234-235.

Hurwit K.N. (1988a) Gem trade lab notes: Augite, Chinese "onyx." Gems $e_{1}$ Gemology, Vol. 24, No. 3, p. 170.

Hurwit K.N. (1988b) Gem trade lab notes: Imitation dyed black chalcedony beads. Gems e Gemology, Vol. 24, No. 4, p. 241.

Hurwit K.N. (1989) Gem trade lab notes: Transparent green augite. Gems et) Gemology, Vol. 25, No. 1, p. 35.

Johnson M.L. (1994) Gem trade lab notes: Magnetic hercynite, a warning about magnetic cards. Gems et Gemology, Vol. 30, No. 1, p. 43.

Johnson M.L. (1995) Gem trade lab notes: Diamond-Fancy black, with iron. Gems et Gemology, Vol, 31, No. 4, p. 266.

Johnson M.L., Kammerling R.C. (1995) Gem trade lab notes: Omphacite, rock carving. Gems \&) Gemology, Vol. 31, No. 2, pp. 124-125.

Johnson M.L., Koivula J.I. (1996) Gem news: "Drusy" silicon, a computer-industry by-product. Gems ev Gemology, Vol. 32, No. 2, pp. 138-139.

Kammerling R.C. (1993) Gem trade lab notes: Orthopyroxene, a carved mask. Gems (4) Gemology, Vol. 29, No. 4, p. 281.

Kammerling R.C., Kane R.E., Koivula J.I., McClure S. F. (1990) An investigation of a suite of black diamond jewelry. Gems (6) Gemology, Vol. 26, No. 4, pp. 282-287.

Kammerling R.C., Koivula J.I., Kane R.E., Fritsch E., Muhlmeister S., McClure S.F. (1991) An examination of nontransparent "CZ" from Russia. Gems $\uplus$ Gemology, Vol. 276, No. 4, pp. 240-246.
Kammerling R., Johnson M.L., Moses M. (1995a) Describing aggregate gem materials. ICA Gazette, February 1995, p. 7.

Kammerling R.C., Koivula J.1., Johnson M.L., Fritsch E. (1995b) Gem news: "Drusy" hausmannite. Gems $\uplus$ Gemology, Vol. 31, No. 3, pp. 207-208.

Kane R.E. (1984) Gem trade lab notes: Cummingtonite-grunerite, a series in the amphibole group. Gems $\Theta$ Gemology, Vol. 20, No. 2, pp. 106-107.

Kane R.E. (1985) Gem trade lab notes: Corundum-Black star sapphire doublet. Gems at Gemology, Vol. 21, No. 3, p. 171.

Kane R.E. (1986a) Gem trade lab notes: Ekanite, a markedly radioactive metamict gem. Gems et) Gemology, Vol. 22, No. l, pp. $47-48$.

Kane R.E. (1986b) Gem trade lab notes: Hornblende amphibole, magnesian hastingsite(?). Gems e) Gemology, Vol. 22, No. 1, p. 49.

Kane R.E. (1986c) Gem trade lab notes: Devitrified glass, cobaltbearing. Gems et) Gemology, Vol. 22, No. 2, p. 108.

Koivula J.I. (1982) Pinpoint illumination: a controllable system of lighting for gem microscopy. Gems \&) Gemology, Vol. 18, No. 2, pp. 83-86.

Koivula J.l., Kammerling R.C. (1989) Gem news: Psilomelane and basalt-novel black carving materials. Gems 4 Gemology, Vol. 25, No. 4, pp. 246-247.

Koivrla J.I., Kammerling R.C. (1990a) Gem news: Star ekanite. Gems (4) Gemology, Vol. 26, No. 1, p. 101.

Koivula J.I., Kammerling R.C. (1990b) Gem news: Black cat'seye opal. Gems \&) Gemology, Vol. 26, No. 4, p. 304.

Koivula J.1., Kammerling R. C. (1991) Gem news: Drusy gems in jewelry. Gems \& Gemology, Vol, 27, No. 1, p. 49.

Koivula J.I., Kammerling R.C., Fritsch E. (1992a) Gem news: Imitations of sugilite and other nontransparent gems. Gems (2) Gemology, Vol. 28, No. 1, p. 66.

Koivula J.l., Kammerling R.C., Fritsch E. (1992b) Gem news: Update on nontransparent CZ. Gems e) Gemology, Vol, 28, No. 2, p. 138.

Koivula J.l,, Kammerling R.C., Fritsch E. (1992c) Gem news: More on irradiated "black" diamonds. Gems \&) Gemology, Vol. 28, No. 4, pp. 276-277.

Koivula J.1., Kammerling R.C., Fritsch E. (1993a) Gem news: Black spinel from Mexico. Gems el) Gemology, Vol. 29, No. 3, pp. 212-213.

Koivula J.1., Kammerling R.C., Fritsch E. (1993b) Gem news: Irradiated phenomenal quartz. Gems (4) Gemology, Vol. 29, No. 4, p. 288.

Koivula J.I., Kammerling R.C., Fritsch E. (1994) Gem news: "Zebra" stones from Australia. Gems e) Gemology, Vol. 30, No. 2, pp. 128-129.

Liddicoat R.T. Jr. (1989) Handbook of Gem Identification. Gemological Institute of America, Santa Monica, California, $364 \mathrm{pp}$.

Moses T. (1989) Gem trade lab notes: Chalcedony, imitation "black onyx." Gems $\Theta$ Gemology, Vol. 25, No. 3, p. 171.

Muller H. (1987) Jet. Butterworth and Company, London, England, $149 \mathrm{pp}$.

Phillips W.R. and Griffen D.T. (1981) Optical Mineralogy. W. H. Freeman and Company, San Francisco, California, $677 \mathrm{pp}$.

Reinitz I., Ashbaugh III C.E. (1992) Gem trade lab notes: Diamond-Treated "black" diamond. Gems \&) Gemology, Vol. 28, No. 2, pp. 124-125.

Webster R. (1994) Gems: Their Sources, Descriptions and Identification, 5 th ed. Rev. by P.G. Read, ButterworthHeinemann Ltd., Oxford, England, 1026 pp.

Welch C. (1987) Gem trade lab notes: Magnetite, lodestone. Gems $\Leftrightarrow$ Gemology, Vol. 23, No. 1, p. 45.

Welch C. (1988) Gem trade lab notes: Unusual glass. Gems $\Theta$ Gemology, Vol. 24, No. 2, p. 113. 